Meta

Journal des traducteurs

Translators' Journal

\title{
Back to basics in the classroom to prepare students for the future workplace: Investigating speed training for translators
}

\section{Lynne Bowker et Cheryl McBride}

Volume 60, numéro 2, août 2015

$60^{\mathrm{e}}$ anniversaire. Les horizons de la traduction : retour vers le futur $60^{\text {th }}$ Anniversary. Translation's Horizons: Back to the Future

60mo aniversario. Los horizontes de la traducción: regreso al futuro

URI : https://id.erudit.org/iderudit/1032865ar

DOI : https://doi.org/10.7202/1032865ar

Aller au sommaire du numéro

Éditeur(s)

Les Presses de l’Université de Montréal

ISSN

0026-0452 (imprimé)

1492-1421 (numérique)

Découvrir la revue

\section{Citer ce document}

Bowker, L. \& McBride, C. (2015). Back to basics in the classroom to prepare students for the future workplace: Investigating speed training for translators. Meta, 60(2), 314-314. https://doi.org/10.7202/1032865ar d'utilisation que vous pouvez consulter en ligne. 


\title{
Back to basics in the classroom to prepare students for the future workplace: Investigating speed training for translators
}

\author{
Lynne Bowker and Cheryl McBride \\ University of Ottawa, Ottawa, Canada \\ lbowker@uottawa.ca; cmcbr014@uottawa.ca
}

There has been a longstanding tension at universities with regard to the "skills vs. knowledge" debate. The press is increasingly reporting on a (perceived) "skills gap" between what employers expect and what graduates offer. Similarly, according to student satisfaction surveys, students want better preparation with regard to "professional skills." Universities are responding by introducing more skills into the curriculum, but they must ensure that such efforts do not undermine the delivery of foundational knowledge.

In translation, a challenge noted by both graduates and employers is the need for new recruits to meet tight deadlines. We have been exploring ways to introduce speed training into the curriculum in a way that allows students to develop the ability to work more quickly, while also giving them the opportunity to reinforce basic skills that are essential to developing a solid foundation in translation. These essentials include the ability to analyze and grasp meaning, to extract key ideas and structure from a text, to organize ideas, to convey ideas accurately and to recognize and avoid distortion in information transfer. The focus of speed training therefore remains firmly rooted in developing critical thinking skills, but with a view to simultaneously cultivating the ability to make informed decisions quickly.

We will report on an investigation in which twenty-one third-year students in the BA in Translation program participated in weekly speed training in the form of précis writing under strict time conditions. Students were surveyed about the experience at the beginning, mid-point and end of the Fall 2014 semester. Their précis were evaluated weekly, and their progress was tracked. The results show that students did improve their ability to work more quickly while still producing quality output, and that while they found the exercise challenging, they appreciated its value and felt better prepared to work under time pressure.

Lynne Bowker holds a PhD in Language Engineering from the University of Manchester Institute of Science and Technology in the United Kingdom. She is Full Professor at the School of Translation and Interpretation at the University of Ottawa, where she teaches and conducts research in translation technologies, language for special purposes, technical translation and translation pedagogy. She is the author of Computer-Aided Translation Technology (2002). Cheryl McBride holds and MA in Translation from the University of Ottawa. She is currently pursuing her PhD in Translation Studies at that same institution, where her research focuses on translation technologies. She has taught numerous undergraduate courses, including courses on FrenchEnglish translation, documentation and lexicography, and translation technologies. 